Nordic Journal of Botany 28: 469-474, 2010

doi: $10.1111 / \mathrm{j} .1756-1051.2009 .00736 . x$,

(C) The Authors. Journal compilation (C) Nordic Journal of Botany 2010

Subject Editor: Arne Strid. Accepted 15 December 2009

\title{
Hypericum scruglii sp. nov. (Guttiferae) from Sardinia
}

\author{
Gianluigi Bacchetta, Salvatore Brullo and Cristina Salmeri
}

S. Brullo (salvo.brullo@gmail.com), Univ. degli Studi di Catania, Dipto di Botanica, Via A. Longo 19, IT-95125 Catania, Italy. - G. Bacchetta, Univ. degli Studi di Cagliari, Dipto di Scienze Botaniche, Centro Conservazione Biodiversità (CCB), Viale S. Ignazio da Laconi 13, IT-09123 Cagliari. - C. Salmeri, Univ. degli Studi di Palermo, Dipto di Scienze Botaniche, Via Archirafi 38, IT-90123 Palermo, Italy.

\begin{abstract}
A new species of Hypericum (Guttiferae) from Sardinia, H. scruglii, is described and illustrated. It occurs on damp soil, near springs or streams with freshwater, where it grows with numerous hygrophytes. This diploid species $(2 \mathrm{n}=16)$ belongs to the sect. Adenosepalum and is closely related to H. tomentosum, a species widespread in the west Mediterranean region.
\end{abstract}

During field investigations in Sardinia, very peculiar populations of Hypericum L. were found occuring on damp soils and limited to calcareous substrates. These plants showed a close morphological and ecological relationship with $H$. tomentosum L., a species belonging to sect. Adenosepalum Spach. As emphasized by Robson (1996), the Sardinian populations of H. tomentosum tend towards $H$. pubescens Boiss. A detailed analysis of living material collected from many localities on the island allowed us to verify that these plants were remarkably different from typical specimens of $H$. tomentosum and, in addition, were totally unlike $H$. pubescens. The Sardinian populations differ from both related species with respect to the shape and size of leaves, floral structures and capsules. Based on this, we concluded that they constitute a new species.

\section{Material and methods}

The investigation is based on numerous plants collected from 11 Sardinian localities, some of which (5) were cultivated in the Botanical Gardens of Cagliari and Catania, as well as on herbarium material at CAG, CAT, FI and TO. In addition, many herbarium specimens of Hypericum tomentosum and $H$. pubescens have been examined at CAT, FI and VAL. Karyological observations were made on mitotic plates from root tip cells of ca 50 germinated seeds, pre-treated for $3 \mathrm{~h}$ with $0.3 \%$ colchicine water solution at room temperature, fixed in Carnoy and stained according to the Feulgen technique. All metaphases were examined using the image analysis systems IKAROS 4.6 (Metasystem) and Zeiss Axiovision 5.1 .

\begin{abstract}
Hypericum scruglii Bacch., Brullo \& Salmeri sp. nov. (Fig. 1, 2)

A Hyperico tomentoso foliis suborbicularibus vel orbiculariellipticis, corolla $18-20 \mathrm{~mm}$ in diametro, sepalis subaequalibus ovato-lanceolatis, acuminatis, $1.2-1.8 \mathrm{~mm}$ latis, petalis irregulariter oblongo-oblanceolatis, $10-11 \mathrm{~mm}$ longis, 3.5$4.5 \mathrm{~mm}$ latis, staminibus $8 \mathrm{~mm}$ longis, antheris $0.4 \mathrm{~mm}$ longis, $0.5 \mathrm{~mm}$ latis, stylis usque ad $4.7 \mathrm{~mm}$ longis, reflexis in fructu, capsula elipsoidea, sepalis longiora, $5.0-6.5 \mathrm{~mm}$ longa, 2.5-2.7 mm lata, loculis longe apiculatis differt.
\end{abstract}

Type: Italy, CE Sardinia, Montarbu di Seui, Nuraghe Ardasai, 39 $53^{\prime} 32.77^{\prime \prime} \mathrm{N}, 9^{\circ} 20^{\prime} 27.90^{\prime \prime} \mathrm{E}, 19 \mathrm{Jul} 2004$, Brullo and Bacchetta, s.n. (holotype: CAT, isotypes: CAG, CAT, FI).

Perennial herb 5-30 cm tall; branches herbaceous, tomentose, prostrate to decumbent, unbranched, rooting in their lower half, the lower internodes almost shorter than their leaves. Leaves sessile, lamina 9-17 ×7-13 mm, suborbicular to orbicular-elliptic, concolorous, green-glaucescent, plane, apex rounded, margin plane, base subcordate; venation in 2-3 basal pairs, curved, ascending and ending freely, 1 upper pair incurved and united at apex; marginal glands black, irregularly distributed and not prominent. Cymes 3-25flowered, from up to 1-3(6) nodes, corymbiform; pedicels 1-3 mm long; bracts not auriculate, bracteoles linearsubulate, with black marginal glands. Flowers 18-20 mm in diameter, buds ellipsoid, obtuse. Sepals 4.0-5.5 $\times 1.2$ $1.8 \mathrm{~mm}$, subequal, ovate-lanceolate, acuminate, with $10-14$ marginal black glands on cilia $0.5-4.0 \mathrm{~mm}$ long and 1 large black gland at the apex, black laminar glands absent; veins 5. Petals bright yellow, $10-11 \times 3.5-4.5 \mathrm{~mm}$, irregularly oblong-oblanceolate, obtuse, apiculus lateral, prominent and acute, dentate in the upper part; interdental black 


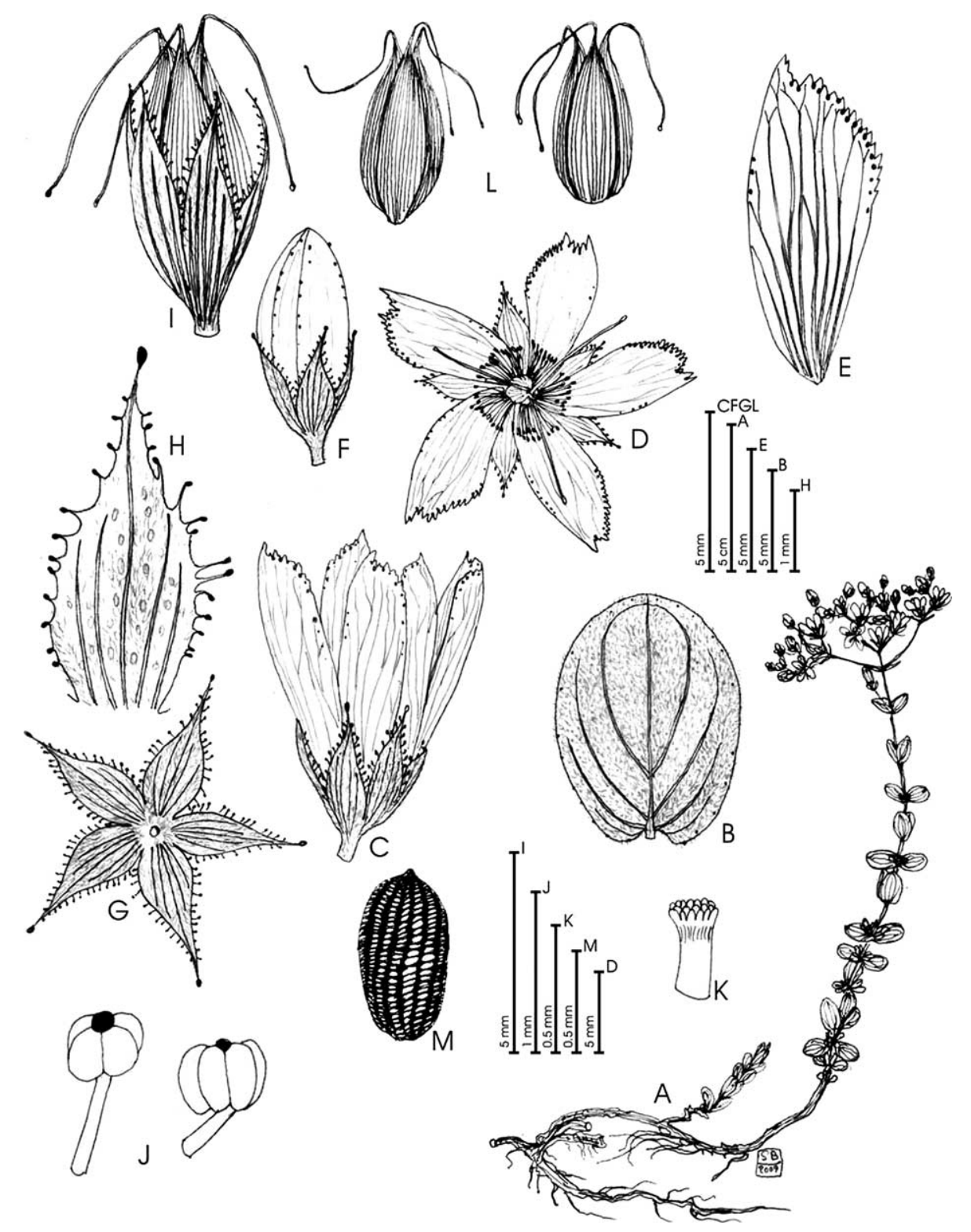

Figure 1. Hypericum scruglii sp. nov. (A) habit, (B) leaf, (C) flower, lateral view, (D) flower, upper view, (E) petal, (F) bud, (G) calyx, (H) sepal, (I) calyx and fruit, (J) anthers, (K) stigma, (L) fruits, (M) seed.

marginal glands few, not prominent. Stamens 33, conspicuosly 3 -fascicled, 3 innermost and 8 outermost, $8 \mathrm{~mm}$ long. Anthers $0.4-0.5 \mathrm{~mm}$, with black gland. Ovary $1.7 \times$ $1.3 \mathrm{~mm}$, narrowly ovoid-pyramidal. Styles up to $4.7 \mathrm{~mm}$ long, reflexed in fruit. Capsule $5.0-6.5 \times 2.5-2.7 \mathrm{~mm}$, ellipsoid, longer than sepals, tridentate with loculi long apiculate. Seed brownish, $0.7-0.9 \mathrm{~mm}$ long, testa finely reticulate-scalariform. Flowering occurs in late Jun-Jul and fruiting in Aug-Sep.

\section{Habitat, distribution and etymology}

Hypericum scruglii is generally linked to calcareous substrates like limestone, conglomerate, travertine, sandstone and marl, where it grows exclusively on damp soil, near springs or streams with freshwater. Occasionally it is possible to find it in pools. It is especially linked to subalkaline and alkaline soils, not much developed from the pedogenetic point of view. It grows under a pluviseasonal Mediterranean bioclimate, within the lower mesoMediterranean and lower supra-Mediterranean belts, with a lower subhumid and lower humid ombrotype. It is a member of hygrophilous plant communities characterized by many Sardinian and Cyrno-Sardinian endemics like Borago morisiana Bigazzi \& Ricceri, B. pygmaea (DC.) Chater \& Greuter, Morisia monanthos (Viv.) Barbey, Polygala sardoa Chodat and Ranunculus cordiger ssp. diffusus (Moris) Arrigoni. Other hygrophytes like Carex flacca Schreb. ssp. serrulata (Biv.) Malagarriga, Mentha pulegium L., Oenanthe pimpinelloides L., Platanthera algeriensis Batt. \& Trab., Schoenus nigricans L. and Solenopsis bivonae (Tineo) M. B. Crespo, Serra \& Juan also occur in the same habitat.

Hypericum scruglii is distributed in centraleast and southeast Sardinia, in particular in the Sarcidano, Barbagia of Seulo, Ogliastra and Quirra areas (Fig. 3). Only two old herbarium specimens are from the Nurra and Sassari 

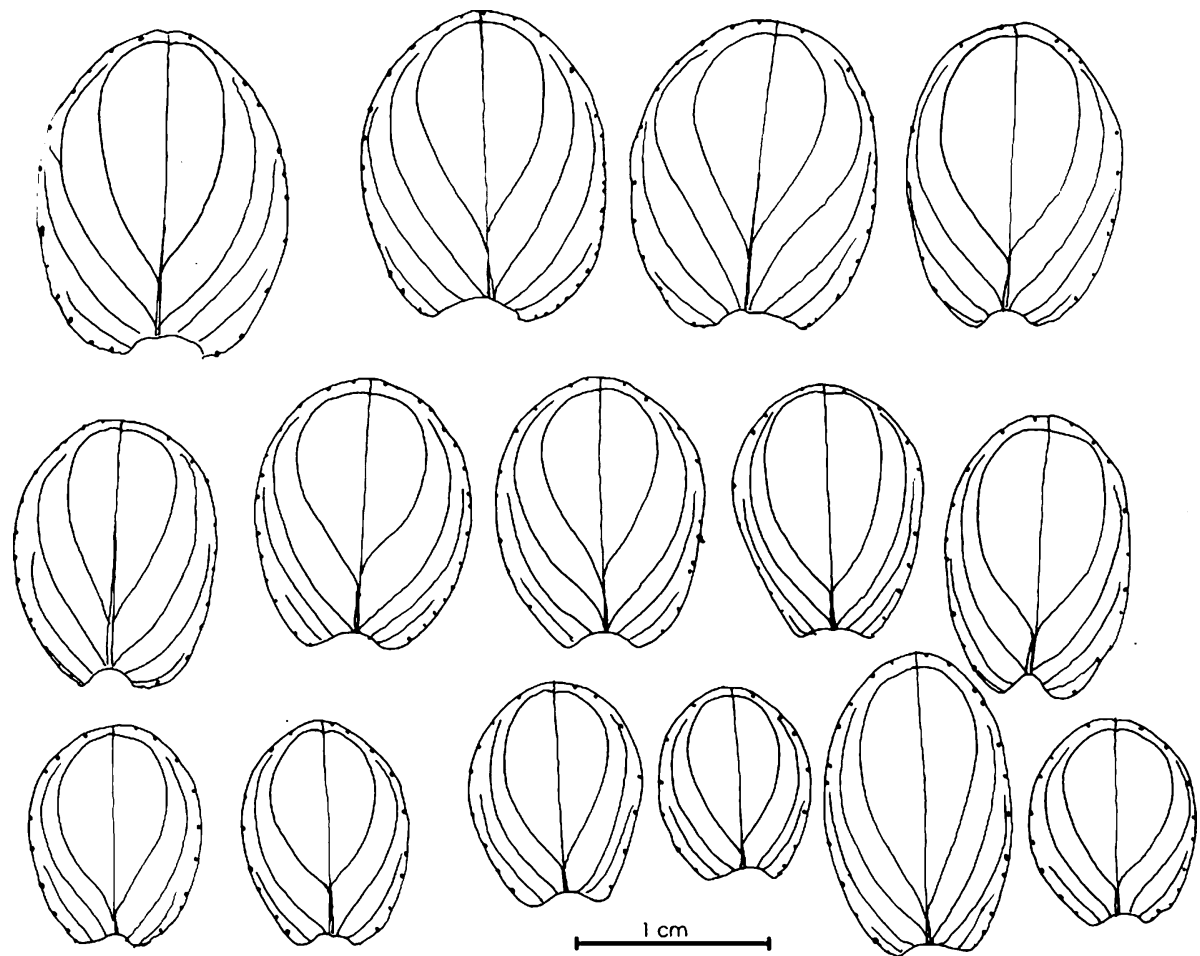

Figure 2. Variability of leaf shape in Hypericum scruglii sp. nov.

districts (northwest Sardinia). However, these records are not quoted by Bagella and Urbani (2006) and need to be confirmed. The species name is given in honour of the Sardinian botanist Antonio Scrugli.

\section{Conservation status}

Presently the populations of $H$. scrugli, although widely distributed, are threatened by overgrazing and human activities (groundwater extraction, roads and manufactures). For this reason it is suggested to be added to the regional red lists of the IUCN, as a 'Vulnerable' species (VU) based on the criteria B1ab (ii, iii, v) $+2 \mathrm{ab}$ (ii, iii, v) (according to IUCN 2001, 2006).

\section{Karyology}

Hypericum scruglii is a diploid species with the somatic chromosome number $2 \mathrm{n}=16$ (Fig. 4). The chromosomes are relatively small, therefore, a detailed, statistically supported karyotypic analysis was not possible. However, the total chromosome length ranges from approximately 2.85 to $0.5 \mu \mathrm{m}$ and some plates clearly show the presence of larger metacentric chromosomes together with punctiform ones. It must be noticed that the same number $(2 \mathrm{n}=16)$ has been reported for the allied species $H$. tomentosum $\mathrm{L}$. (from Portugal, Queiros 1991, Robson 1996).

\section{Discussion and conclusions}

In the classification proposed by Robson $(1968,1996)$ and Ramos Nuñez (1983, 1993), H. scruglii belongs in sect. Adenosepalum Spach owing to its pubescent branches and leaves, black glands on leaves, sepals, petals and anthers,

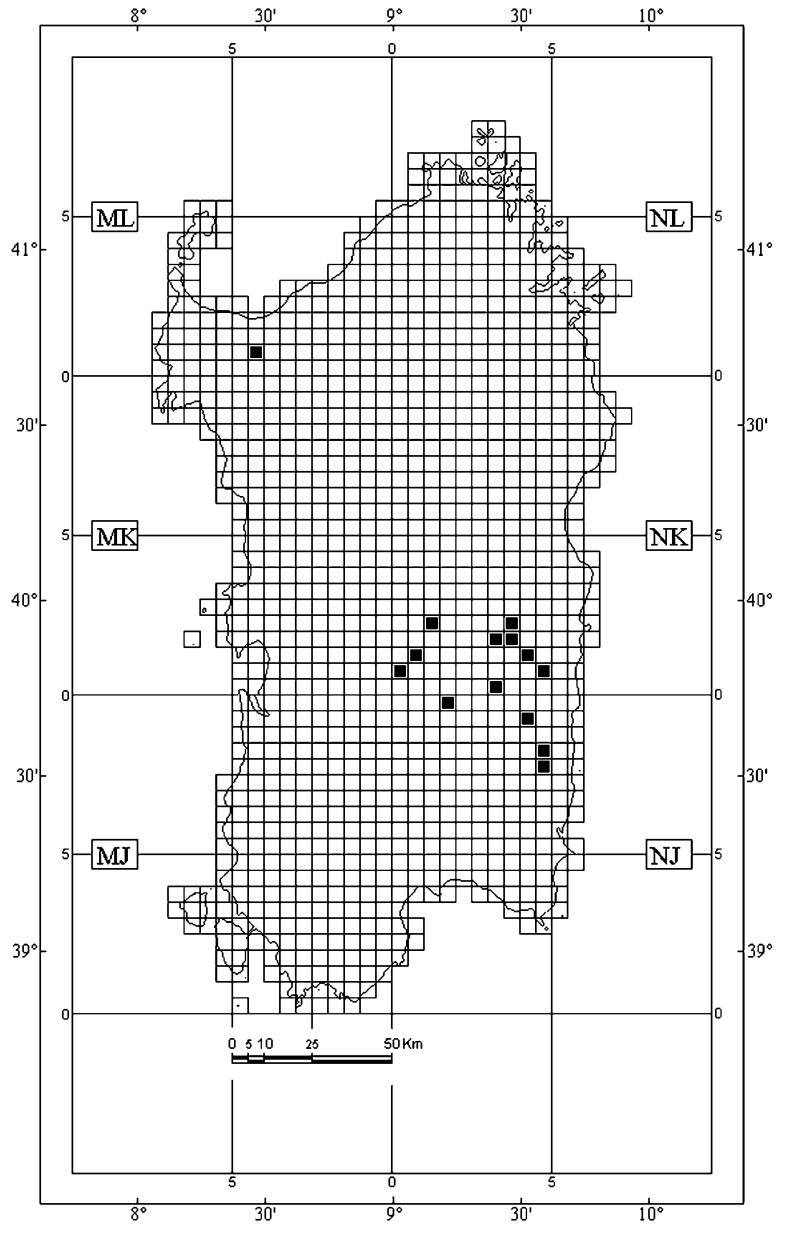

Figure 3. Geographical distribution of Hypericum scruglii sp. nov. in Sardinia. 


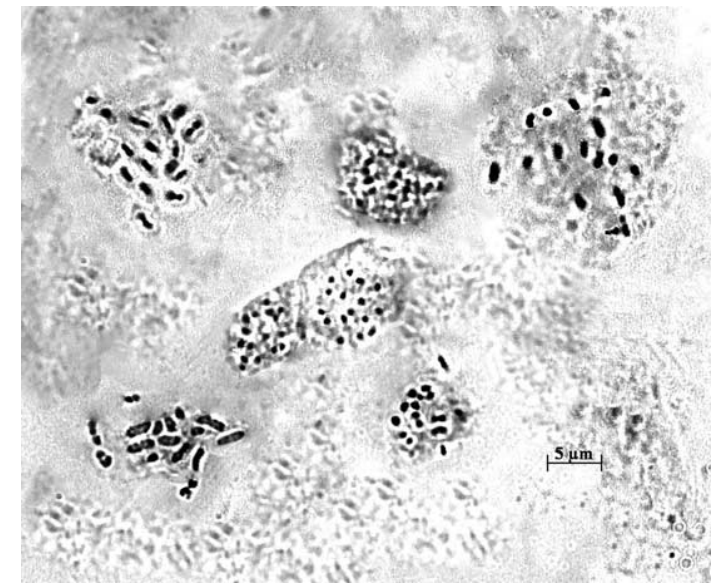

Figure 4. Mitotic metaphase plates $(2 \mathrm{n}=16)$ of Hypericum scruglii sp. nov.

as well as 3 stamen fascicles, 3 styles and reticulate and scalariform seeds. Robson (1977, 1993) recognized four subsections within this section and $H$. scruglii may be included in subsect. Pubescentes N. Robson. Within this subsection, H. scruglii shows a close relationship to $H$. tomentosum. Both these species are characterized by sepals up to $5.5 \mathrm{~mm}$ long with black, ciliate marginal glands and petals up to $11 \mathrm{~mm}$ long. However, as outlined in Table 1, there are significant morphological differences between $H$. tomentosum (Fig. 5) and H. scruglii.

The Sardinian material preserved in the Moris herbarium (TO!), as well as the description and illustration of $H$. tomentosum from Sardinia given by Moris (1837), correspond very well to the populations that we attribute to $H$. scruglii. On the basis of our herbarium investigations, we conclude that the Sardinian records of $H$. tomentosum quoted by Fiori (1924), Robson (1968) and Pignatti (1982) must be referred to $H$. scruglii.

Robson (1996) examined a specimen collected by Müller at Laconi $(\mathrm{H}, \mathrm{K})$, and formulated the hypothesis that the Sardinian populations of $H$. tomentosum belong to a hybrid taxon verging towards $H$. pubescens. We do not believe in this hypothesis, mainly because neither of the proposed parental species do occur in Sardinia. In addition, $H$. scruglii differ markedly from $H$. pubescens as outlined in Table 1. Many of these morphological characters can be observed on the Iberian material in the detailed iconography published by Boissier (1840, Table 36). Further, Hypericum tomentosum and $H$. pubescens have different chromosome numbers, $2 \mathrm{n}=16$ and $2 \mathrm{n}=18$ or 36 , respectively (Reynoud 1986, Ramos Nuñez 1987, Queiros

Table 1. Diagnostic morphological characters of Hypericum scruglii, H. tomentosum and $H$. pubescens.

\begin{tabular}{|c|c|c|c|}
\hline Characters & H. scruglii & H. tomentosum & H. pubescens \\
\hline Habit & perennial herb, $5-30 \mathrm{~cm}$ tall & perennial herb, 9-53(90) $\mathrm{cm}$ tall & perennial herb, $10-70 \mathrm{~cm}$ tall \\
\hline Branches & $\begin{array}{l}\text { herbaceous, prostrate to decumbent, } \\
\text { unbranched, rooting in the lower half, } \\
\text { the lower internodes almost shorter } \\
\text { than the leaves }\end{array}$ & $\begin{array}{l}\text { partially woody, erect or decumbent to } \\
\text { prostrate, branching and sometimes } \\
\text { rooting at base, internodes longer than } \\
\text { the leaves }\end{array}$ & $\begin{array}{l}\text { herbaceous, erect or decumbent and } \\
\text { rarely prostrate, unbranched, internodes } \\
\text { almost longer than the leaves }\end{array}$ \\
\hline Leaves & $\begin{array}{l}\text { sessile, lamina } 9-17 \times 7-13 \text {, } \\
\text { suborbicular to orbicular-elliptic, } \\
\text { concolorous, green-glaucescent, apex } \\
\text { rounded, base subcordate }\end{array}$ & $\begin{array}{l}\text { sessile, lamina } 5-26 \times 2-11 \mathrm{~mm} \text {, } \\
\text { elliptic-oblong to triangular-ovate, } \\
\text { concolorous, green, apex rounded to } \\
\text { obtuse, base cuneate to truncate or } \\
\text { subcordate }\end{array}$ & $\begin{array}{l}\text { sessile, lamina } 6-40 \times 2-16 \mathrm{~mm} \text {, narrow } \\
\text { oblong to oblong-oblanceolate, } \\
\text { concolorous, green, apex subobtuse to } \\
\text { rounded, base rounded to cordate- } \\
\text { amplexicaul }\end{array}$ \\
\hline Cymes & $\begin{array}{l}3-25 \text {-flowered, from up to } 1-3(6) \\
\text { nodes, corymbiform }\end{array}$ & $\begin{array}{l}\text { 3-70-flowered, from up to } 3 \text { nodes, } \\
\text { curved-corymbiform to cylindric }\end{array}$ & $\begin{array}{l}\text { 3-5-flowered, from up to } 3 \text { nodes, } \\
\text { curved-corymbiform }\end{array}$ \\
\hline Bracteoles & linear-subulate & linear & linear \\
\hline Flowers & $\begin{array}{l}\text { 18-20 mm in diameter, buds ellipsoid, } \\
\text { obtuse }\end{array}$ & $\begin{array}{l}10-15(20) \mathrm{mm} \text { in diameter, buds } \\
\text { ellipsoid, obtuse to rounded-obtuse }\end{array}$ & $\begin{array}{l}15-30 \mathrm{~mm} \text { in diameter, buds cylindric- } \\
\text { ellipsoid, obtuse }\end{array}$ \\
\hline Sepals & $\begin{array}{l}4.0-5.5 \times 1.2-1.8 \mathrm{~mm} \text {, subequal, ovate- } \\
\text { lanceolate, acuminate, with } 10-14 \\
\text { marginal black glands on each side, on } \\
\text { cilia } 0.5-4.0 \mathrm{~mm} \text { long, laminar black } \\
\text { glands absent but with big black apical } \\
\text { gland, veins } 5\end{array}$ & $\begin{array}{l}3-5 \times 2.5-3.5 \mathrm{~mm} \text {, subequal to unequal, } \\
\text { lanceolate to ovate or broadly elliptic, } \\
\text { acute to usually shortly aristate, with } \\
8-16 \text { marginal black glands on each } \\
\text { side, on cilia } 0-1 \mathrm{~mm} \text { long, with black } \\
\text { laminar glands and big black apical } \\
\text { gland, veins (3)5-7 }\end{array}$ & $\begin{array}{l}5-10 \times 1.5-2.5 \mathrm{~mm} \text {, subequal, linear- } \\
\text { lanceolate to lanceolate, long aristate, } \\
\text { with } 3-5 \text { sessile marginal black glands on } \\
\text { each side, laminar and apical black } \\
\text { glands absent, veins } 3(5)\end{array}$ \\
\hline Petals & $\begin{array}{l}10-11 \times 3.5-4.5 \mathrm{~mm} \text {, irregularly oblong- } \\
\text { oblanceolate, obtuse, apiculus lateral, } \\
\text { prominent and acute, dentate in the } \\
\text { upper part; interdental marginal glands } \\
\text { black and few, not prominent }\end{array}$ & $\begin{array}{l}6-9 \times 2.5-3.5 \mathrm{~mm} \text {, oblanceolate, } \\
\text { rounded, apiculus lateral, shortly acute } \\
\text { to absent, entire or slightly dentate in the } \\
\text { upper part; marginal to inframarginal } \\
\text { glands black, few, subterminal and not } \\
\text { prominent }\end{array}$ & $\begin{array}{l}\text { 9-15 } \times 3.0-6.5 \mathrm{~mm} \text {, oblanceolate, } \\
\text { rounded, apiculus lateral, apiculate or } \\
\text { absent, entire or slightly dentate in the } \\
\text { upper part; marginal to inframarginal } \\
\text { glands black, few, not or scarsely } \\
\text { prominent }\end{array}$ \\
\hline Stamens & $\begin{array}{l}33 \text {, clearly } 3 \text {-fascicled, } 3 \text { inner and } \\
8 \text { outer, } 8 \mathrm{~mm} \text { long }\end{array}$ & $\begin{array}{l}25-35 \text {, clearly } 3 \text {-fascicled, longest } \\
5-7 \mathrm{~mm}\end{array}$ & $\begin{array}{l}\text { 30-50, clearly } 3 \text {-fascicled, longest } \\
6-11 \mathrm{~mm}\end{array}$ \\
\hline Anthers & $0.4 \mathrm{~mm}$ long and $0.5 \mathrm{~mm}$ wide & $0.5 \mathrm{~mm}$ long and $0.8 \mathrm{~mm}$ wide & $0.6 \mathrm{~mm}$ long and $0.4 \mathrm{~mm}$ wide \\
\hline Ovary & $1.7 \times 1.3 \mathrm{~mm}$, narrowly ovoid-pyramidal & $\begin{array}{l}1.5-2.0 \times 1.0-1.3 \mathrm{~mm} \text {, narrowly } \\
\text { ovoid-pyramidal }\end{array}$ & $2-3 \times 1-2 \mathrm{~mm}$, ovoid-elipsoid to elypsoid \\
\hline Style & up to $4.7 \mathrm{~mm}$ long; reflexed in fruit & $5.0-6.3 \mathrm{~mm}$ long; patent in fruit & 5-7 mm long; spreading-incurved in fruit \\
\hline Capsule & $\begin{array}{l}5.0-6.5 \times 2.5-2.7 \mathrm{~mm} \text {, ellipsoid, longer } \\
\text { than sepals, tridentate with loculi } \\
\text { longely apiculate }\end{array}$ & $\begin{array}{l}4-5 \times 3-4 \mathrm{~mm} \text {, ovoid-subglobose, } \\
\text { shorter than sepals, truncate with } \\
\text { loculi rounded at apex }\end{array}$ & $\begin{array}{l}6-7 \times 3.5-5.0 \mathrm{~mm} \text {, ovoid, shorter than } \\
\text { sepals, tridentate with loculi short } \\
\text { apiculate at apex }\end{array}$ \\
\hline Seed & $\begin{array}{l}\text { brownish, } 0.7-0.9 \mathrm{~mm} \text { long, testa } \\
\text { finely reticulate-scalariform }\end{array}$ & $\begin{array}{l}\text { greyish-brown, } 0.9-1.0 \mathrm{~mm} \text { long, } \\
\text { testa finely reticulate-scalariform }\end{array}$ & $\begin{array}{l}\text { purplish, } 0.6-1.0 \mathrm{~mm} \text { long, testa finely } \\
\text { scalariform }\end{array}$ \\
\hline
\end{tabular}




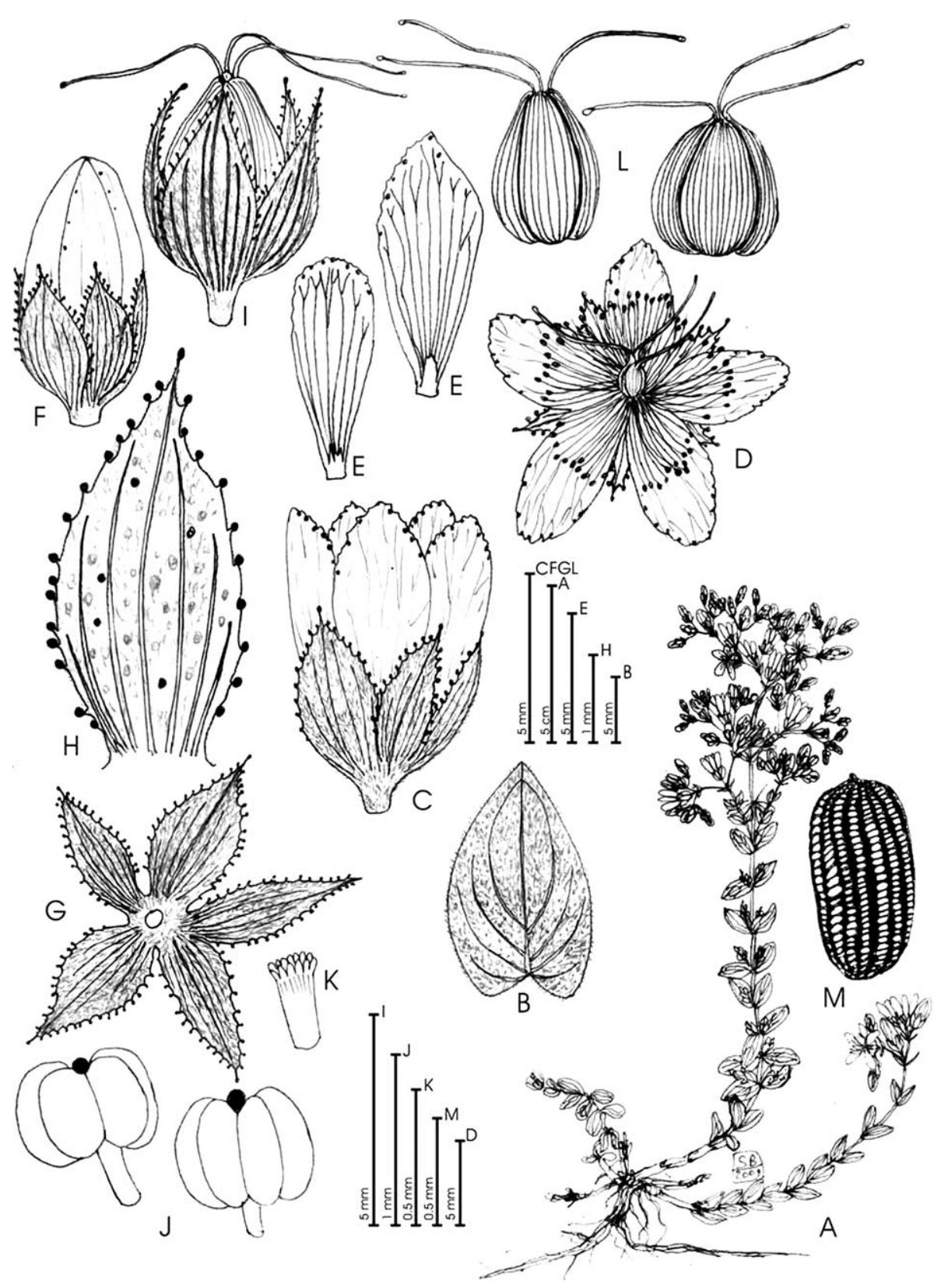

Figure 5. Hypericum tomentosum. (A) habit, (B) leaf, (C) flower, lateral view, (D) flower, upper view, (E) petals, (F) bud, (G) calyx, (H) sepal, (I) calyx and fruit, (J) anthers, (K) stigma, (L) fruits, (M) seed.

1991, Robson 1996). Therefore, H. scruglii, being a diploid species with $2 \mathrm{n}=16$, is very unlikely to have evolved from a hybridization process between these two taxa.

In conclusion, based on our morphological and karyological observations, we hypothesize that $H$. scruglii arose from populations of $H$. tomentosum as a consequence of geographical isolation.

Acknowledgements - We thank the keepers and curators of the following herbaria: FI, TO, CAG, CT and VAL.

\section{Additional specimens examined}

Hypericum scruglii Bacch., Brullo \& Salmeri (paratypes):

Sardinia. In apricis collinis, Sardinia, Jun-Jul, Moris (FI); In pratis prasertum maritimis, May, Moris 237 (TO); Ad vias inter Esterzili et Nurra, Jul 1826, Moris (TO); In Sardinia orientalis Perdas de Fogu, May, Moris (TO); In umentibus presso Sassari, 1840, Lisa (TO); Contorni d'Isili, Jul 1860, Gennari (FI); Ad rivulos Horti Marchionas de Laconi, 25 Jun 1863, Ascherson (FI); Laconi, Pauli, 8 Jun 1864, sine leg. (TO); Ibid., 20 Aug 1864, sine leg. (TO); Laconi, boschetto, 25 Jun 1864, sine leg. (TO); Laconi, Pauli gora, 27 Aug 1869, sine leg. (TO); Ulassai, alla Corci, luoghi umidi, 1 Aug 1894, Martelli (FI); Isili, in collibus, 15 May 1894, Martelli (FI); Isili, Sep 1901, Cavara \& Grande (FI); Circondario di Aritzo, 1935, Porcu (FI); Genn'i Acca (Montarbu - Seui), 8 Jun 2001, Bacchetta, Brullo, Casti \& Giusso (CAT); M. te Tonneri, rivoli presso il Nuraghe di Ardasai, 8 Jun 2001, Bacchetta, Brullo, Casti \& Giusso (CAT); Sa Scala e sa Marra, Seui (NU), 9 Jun 2001, Bacchetta, Brullo, Casti, Català \& Giusso 163/01 (CAG, CAT); Mura Gessa, Seui (NU), 9 Apr 2002, Bacchetta, Casti, Iiriti, Pontecorvo \& Serra 85/02 (CAG); Santa Sofia, Laconi (NU), 23 Apr 2002, Bacchetta, Casti \& Pontecorvo 156/02 
(CAG); Baccu Locci, San Vito (CA), 26 May 2002, Bacchetta, Brullo, Casti \& Giusso 255/02 (CAG); Salto di Quirra, 26 May 2002, Bacchetta, Brullo, Casti \& Giusso s.n. (CAT); Funtana is Breccas, Osini (NU), 5 Jun 2002, Bacchetta \& Casti 372/02 (CAG); Funtamela, Laconi (NU), 6 Jun 2003, Bacchetta, Pirodda, Podda \& Pontecorvo 383b/03 (CAG); S’Atza e Ziu Chiccu, Laconi (NU), 25 Jun 2003, Bacchetta, Carrió, Casti \& Herreros 396/03 (CAG); Nuraghe Ardasai, Seui (NU), 19 Jul 2004, Angius, Bacchetta, Brullo \& Mattana 427/04 (CAG).

Hypericum tomentosum L.

Italy. Liguria occid. S. Remo, preso gli Ospedaletti, May, Panizzi (FI); Sopra Monti Sterili in sassosis verso Porto fino Rapallo-Ruta, 7 Jul 1823, Figaro (FI); Bordighera, luoghi umidi, Jul, Ricca (FI); Lieux humides prés la mer Ospedaletti, Liguria, 22 Jun 1878, Buknell (FI).

France. Lieux humides Aix, B. du Rhône, 9 Jun 1867, Courciore (FI); Fossés humidis sur les bordes de l'Etange de Marignane (B. du Rh.), Jun 1869, Martigue (FI); Nice, region littorale, St André, 16 Jul 1883, Barla (FI); Valacloche, lieux humides et herbeux sur le calcaire, $800 \mathrm{~m}$ a.s.l., Jul 1893, Reverchon 626 (FI); Herault, Perola à l'Estelle, 8 Aug 1895, Sennen (FI).

Spain. Environs de Cadiz, s.d., Fée (FI); Bordes de la riviére a Riopar, 20 Jul 1850, Bourgeau 603 (FI); Bordes du lac de l'Albufera prés de Valencia, 4 Jul 1852, Bourgeau 1582 (FI); Costal de Fels (Barcelone), 30 May 1871, Compañó (FI); Costal de Fels, province de Barcelone, Espagne, dans les bordes des zone estagnales bord de la mer, Jun 1873, Tremols (FI); Barcelone, in pratis humidis litoralis, Jun 1874, Castellantely (FI); Balearen insula Majore, in agris sterilibus paludosis prope Pagum Artá, 30 Jun 1885, Porta \& Rigo (FI); Valence, Segorbe, lieux humides et torbeux sur les alluvions du Rio, $350 \mathrm{~m}$ a.s.l., Aug 1891, Reverchon 626 (FI); Catalogne, Llers ruisseau, 14 Jul 1907, Sennen 273 (FI); Catalogne, Llers, fossées et pelouses humides, 1 Aug 1907, Sennen 422 (FI, VAL); Sierra de Corteza, Jun 1945 , Borja 787 (VAL); Madrid, Guadalix de la Sierra, en suelo cretácico, 25 Jul 1948, Rivas Goday (VAL); Alicante, Barranco de Chirles, en el Molinio-Holoscenion, 12 Aug 1958, Rigual s.n. (VAL); Mallorca, sitios frescos y humedos, Lluc, 4 Aug 1959, Palau Ferrer 215 (VAL); Alicante, Vall de Ebo, 11 Jul 1962, Rigual 22078 (VAL); Soria, Berlanga de Duero, 900 m a.s.l., Jul 1975, Mateo 75/207 (VAL); Valencia, Barig, 300 m a.s.l., Sep 1976, Mateo, Mansanet \& Puche (VAL); Valencia, Dos Aguas, en el Cirsio-Holoschoenetum, 15 May 1984, Peris \& Stübing (FI); Alava, Espejo, $540 \mathrm{~m}$ a.s.l., zona encharcada arcillosa, $31 \mathrm{Jul}$ 1985, Morante \& Morante VIT 547.85 (VAL); Valencia, Rozalemes (Requena), XY67, 700 m a.s.l., 15 Jul 1986, García (VAL); Valencia El Brull, neixement del Vinalopó, Bocairent, $740 \mathrm{~m}$ a.s.l. 27 Sep 1987, Nebot (VAL); Teruel, Beceite, salida hacia el Parrizal, $575 \mathrm{~m}$ a.s.l., 12 Sep 1991, Fabregat (VAL); Alicante, Teulada, bco. de la font de l'Horta, 100 m a.s.l., 30 Jun 1995, Soler \& Signes 1826 (VAL).

Hypericum pubescens Boiss.

Italy. Favignana, 14 Apr 1973, Brullo (CAT); Gorghi Tondi, Mazzara del Vallo, 27 Sep 1973, Brullo (CAT); Levanzo, 4 Jul 1982, Brullo (CAT); Favignana, 15 Jun 1983, Brullo (CAT).
Malta. Wied Babu, 27 Jun 1973, Brullo \& Ronsisvalle (CAT); Misvan Ghonoa, 28 Jun 1973, Brullo \& Ronsisvalle (CAT); Xilendi Valley, 29 Jun 1973, Brullo \& Ronsisvalle (CAT); Mosta, 4 Apr 1984, Brullo \& Ronsisvalle (CAT); Qrejten Point, 9 Apr 1984, Brullo \& Ronsisvalle (CAT).

\section{References}

Bagella, S. and Urbani, M. 2006. Vascular flora of the calcareous outcrops in northwestern Sardinia (Italy). - Webbia 61: 95-132.

Boissier, E. 1840. Voyage botanique dans le midi de l'Espagne pendant l'année 1837. 2. - Gide et C. . $^{\text {, Paris. }}$

Fiori, A. 1924. Nuova flora analitica d'Italia 1. - M. Ricci, Firenze.

IUCN 2001. The IUCN red list categories and criteria, ver. 3.1. - IUCN Species Survival Commission.

IUCN 2006. Guidelines for using the IUCN red list categories and criteria, ver. 6.1. - IUCN Species Survival Commission.

Moris, J. H. 1837. Flora Sardoa, seu historia plantarum in Sardinia et adjacentibus insulis vel sponte nascentium vel ad utilitatem latius excultarum. 1. - Ex Regio Thypographeo, Taurini.

Pignatti, S. 1982. Flora d'Italia. 1. - Edagricole, Bologna.

Queiros, M. 1991. Números cromossómicos de algumas especies Portuguesas de Hypericum. - Rev. Biol. Univ. Oviedo 9: 51-57.

Ramos Nuñez, A. 1983. Estudio biosistemático del género Hypericum L. (Guttiferae) en la Península Ibérica e Islas Baleares. 1. Caracteres seminales. - Trab. Dep. Bot. 12: 45-62.

Ramos Nuñez, A. 1987. Clusiaceae. - In: Valdes, B. et al. (eds), Flora vascular de Andalucía occidental. 1. Ketres Editora, Barcelona, pp. 314-318.

Ramos Nuñez, A. 1993. Hypericum L. - In: Castroviejo, S. et al. (eds), Flora Iberica. Vol. 3. CSIC Real Jard. Bot., Madrid, pp. $157-185$.

Reynaud, C. 1986. Étude cytotaxonomique des millepertuis du Bassin meditérranéen et des Îles Canaries. - Bull. Soc. Bot. Fr., Lett. Bot. 2, 133: 167-177.

Robson, N. K. B. 1968. Hypericum L. - In: Tutin, T. G. et al. (eds), Flora Europaea. Vol. 2. Cambridge Univ. Press, pp. 261-269.

Robson, N. K. B. 1977. Studies in the genus Hypericum L. (Guttiferae), 1. Infrageneric classification. - Bull. Br. Mus. Nat. Hist. 5: 294-355.

Robson, N. K. B. 1993. Studies in Hypericum: validation of new names. - Bull. Nat. Hist. Mus. Lond. Bot. 23: 67-70.

Robson, N. K. B. 1996. Studies in the genus Hypericum L. (Guttiferae), 6. Sect. 20 Myriandra to 28 Elodes. - Bull. Nat. Hist. Mus. Lond. Bot. 26: 75-217. 